\title{
Rehabilitation in Osteoporosis - therapeutic chalenge?
}

\section{STANCIU Liliana-Elena ${ }^{1,2^{*}}$, IONESCU Elena-Valentina ${ }^{1,2}$, OPREA Carmen $^{1,2}$, ALMĂȘAN Elena-Roxana ${ }^{1,2}$, VRĂJITORU Andreea-Bianca ${ }^{1}$, ILIESCU Mădălina Gabriela ${ }^{1,2}$}

\author{
Corresponding author: Stanciu Liliana-Elena, E-mail: lilianastanciu77@yahoo.com
}

1. Balneal and Rehabilitation Sanatorium of Techirghiol, Constanta, Romania 2. Faculty of Medicine, „Ovidius” University of Constanta, Romania

\begin{abstract}
Introduction. Osteoporosis is a disease of the entire skeleton, characterized by decrease bone mass and microarhitectural alterations of bone tissue, which result in increased bone fragility and predisposition to bone fractures. Materials and methods. Accesing standard medical databases: Medline, Embase, Database, Pubmed and the Cochrane Register of Controled Studies to review new pharmacological studies and non-pharmacological terapies in osteoporosis. Statistical analysis performed from the data extracted from the observation sheets from June 2019 to December 2019 by Dr. Liliana Stanciu. Results and discussions. The complex balneo-physical-kinetic treatment is an important link in the treatment of the disabling pathology for the patient, with an important clinical resonance. Conclusion. Osteoporosis is a pathology that decreases the patient's quality of life. There are complementary therapies to pharmacological treatment with immediate and long lasting results.
\end{abstract}

Keywords: mud, osteoporosis, balneal, hormones,

\section{Introduction}

Osteoporosis is a progressive systemic skeletal disease (1) characterised by decreased bone mineral density and microarchitectural damage of bone tissue with increased susceptibility to fractures (2), which can subsequently cause a functional deficit, with decreased quality of life, in the absence of an adapted medical rehabilitation program. Osteoporosis classification criteria published by World Health Organization (WHO) according to DXA (dual energy X-ray absorptiometry) osteodensitometry are as follows, represented in Table 1.

Table 1 Data from Kanis et al (3).

\begin{tabular}{|l|l|}
\hline Classification & T-score \\
\hline Normal mass & Between-1.0 and -2.5 \\
\hline $\begin{array}{l}\text { Low bone } \\
\text { (osteopenia) }\end{array}$ & $\leq-2.5$ \\
\hline Osteoporosis & $\begin{array}{l}\leq-2.5 \text { with one or more } \\
\text { fractures }\end{array}$ \\
\hline $\begin{array}{l}\text { Severe or established } \\
\text { osteoporosis }\end{array}$
\end{tabular}

Most women with osteoporosis are asymptomatic, which makes epidemiological research especially difficult (4). The main factors associated with low bone mineral density (BMD) are old age, menopause, a history of previous fractures and smoking. Women with a higher body mass index who performed regular physical activity and followed hormone replacement therapy had a lower prevalence of low bone mineral density (5). Recently, Baccaro et al. reported that female patients with osteoarthritis who are going through menopause for a longer period of time, have balance disorders, associated functional deficit, have a higher prevalence of osteoporosis (6). Additional skeletal and extra-skeletal factors, such as bone geometry, microdamage, mineralization, age, and a wide range of clinical risk factors, including family history, previous fracture, and fall risk, contribute to the overall assessment of fracture risk (7-10). Many of these factors are identified with FRAX score. It estimates the 10-year probability of hip fracture and major osteoporotic fracture based on individual's risk profile (11). Several determined factors are the subject of clinical research (12-19) using new imaging techniques, such as Quantitative Computed Tomography (QCT) and High Resolution (Peripheral) QCT $(20,21)$ and minimally invasive approaches for establishing the structure of bone material (22). Although there is evidence of their predictive capacity for fractures $(23,24)$, none of these modalities appear to reliably exceed BMD in predicting different types of osteoporotic fractures, and their general lack of availability and validation in the clinical setting only attributes an adjunct role to the determination of BMD measured by DXA. In contrast, trabecular bone score (TBS) is a new imaging technique, based on standard DXA imaging and appears to be an index of bone texture that provides additional skeletal information to standard BMD results (25).TBS is not a direct measure of bone microarchitecture, but is related to $3 \mathrm{D}$ bone characteristics, such as number of trabeculae, trabecular organization, and connection density $[26,27]$. A high TBS seems to represent a strong, fracture-resistant microarchitecture, while a low TBS reflects a weak, fracture-prone microarchitecture. Thus, there is evidence that TBS can differentiate between two three-dimensional (3D) microarchitectures that have the 
same bone density but different trabecular features. TBS is generally obtained by reanalysing DXA images of lumbar spine AP, which allows direct comparison with a BMD and application to existing data sets. The latter opportunity has led to a rapid increase of published research assessing its potential role in the evaluation and management of osteoporosis. Lumbar TBS, like BMD, is an age-dependent variable. There are few changes in TBS between the ages of 30 and 45 years. Subsequently, there is a progressive decrease with age (28), which is more relevant in women than in men. The decrease percentage with age is similar to that for the lumbar spine of BMD, as well as short-term reproducibility (26).

Spinal radiography is of particular importance for patients at risk for osteoporosis, as the presence of asymptomatic vertebral fractures significantly increases the risk of new fractures, both axial and peripheral, (29) and may change the therapeutic approach, especially in patients with osteopenia. Spinal radiographs should be performed for women who have dropped $\geq 2.5 \mathrm{~cm}$ in height over a 2 -year period, with associated pain or changes of vertebral static, as well as for people with chronic glucocorticoid use $(30,31)$.

\section{Material and method}

Accesing standard medical databases: Medline, Embase, Database, Pubmed and the Cochrane Register of Controled Studies to review new pharmacological studies and non-pharmacological terapies in osteoporosis. A retrospective study was performed on the consultation sheets of patients hospitalised within Balneal and Rehabilitation Sanatorium of Techirghiol during JuneDecember 2019, with attending physician Dr.Stanciu Liliana. The rehabilitation treatment applied daily to the patients included in the study during the hospitalization consisted of peloidotherapy and hydrokinetotherapy in the therapeutic pool with water from Techirghiol Lake or in Techirghiol Lake during the summerand adjuvant procedures (electrotherapy, physiotherapy, massage therapy)(32,33). The study was carried out with the approval of Ethics Council within Balneal and Rehabilitation Sanatorium. Considering a total number of 453 hospitalizations performed during the study period, a number of 83 patients presented a diagnosis of Osteoporosis / Osteopenia, a pathology that is a criterion of inclusion in the study. The items considered in the statistical analysis were the following:

1. Age

2. Gender

3. Area of origin

4. Body weight and height (BMI)

5. Diagnosis and date of diagnosis

6. Axial T-score, peripheral T-score, DXA

on bone mineral density assessment (BMD)

7. VAS at hospital admission and VAS at discharge

8. Mud and baths
9. Presence/absence of fragility fractures

10. Associated pathology

11. Medication

\section{Results and discussions}

In this scientific approach, 453 consultation sheets were included in the study among the patients hospitalised at Balneal and Rehabilitation Sanatorium of Techirghiol. Of these, only 83 consultation sheets $(18.32 \%)$ were included in the study. The remaining 370 patients $(81.68 \%)$ were not diagnosed with Osteoporosis/ Osteopenia (Table 2).

Table 2. Included in the study

\begin{tabular}{|ll|l|l|}
\hline & & Frequency & Percent \\
\hline Valid & Yes & 83 & 18.32 \\
& No & 370 & 81.68 \\
& Total & 453 & 100.00 \\
\hline
\end{tabular}

Predominant patients from our study are aged between $60-70$ years, with a number of 47 people $(56.63 \%)$. Between the ages of 70 and 80 years, there were 20 patients $(24.10 \%)$, and the category with the fewest patients was between 50-60 years, with only 16 patients (19.28\%), according to table 3 .

Table 3. Age (in years)

\begin{tabular}{|ll|l|l|}
\hline & & Frequency & Percent \\
\hline Valid & {$[50-60)$} & 16 & 19.28 \\
& {$[60-70)$} & 47 & 56.63 \\
& {$[70-80)$} & 20 & 24.10 \\
& Total & 83 & 100.00 \\
\hline
\end{tabular}

The evaluation of patients in the present scientific research reported that a number of 2 patients $(2.41 \%)$ were men and the remaining 81 patients $(97.59 \%)$ were women, a major difference between the proportion of patients in terms of item studied, namely the gender (Table 4).

Table 4. Gender

\begin{tabular}{|ll|l|l|}
\hline & & Frequency & Percent \\
\hline Valid & Female & 81 & 97.59 \\
& Male & 2 & 2.41 \\
& Total & 83 & 100.00 \\
\hline
\end{tabular}

Only a number of 13 patients $(15.66 \%)$ came from rural areas, and the remaining 70 patients $(84.34 \%)$ from urban areas, probably due to a greater addressability to medical recovery services (Table 5).

Table 5. Area of origin

\begin{tabular}{|ll|l|l|}
\hline & Frequency & Percent \\
\hline Valid & Urban & 70 & 84.34 \\
& Rural & 13 & 15.66 \\
& Total & 83 & 100.00 \\
\hline
\end{tabular}


The statistical analysis of patients in the study revealed that the diagnosis of Osteopenia $(\mathrm{Op})$ predominated with a number of 46 patients, $55.42 \%$. A number of 13 patients, $15.66 \%$ were diagnosed with Osteoporosis (OP) Type I- post menopause, $25.30 \%, 21$ patients with senile OP Type II. Only a number of 3 patients, $3.61 \%$ were diagnosed with axial OP, concomitantly with peripheral Op (Table 6).

Table 6. Types of osteoporosis

\begin{tabular}{|ll|l|l|}
\hline & Frequency & Percent \\
\hline Valid & Op & 46 & 55.42 \\
& OP Type I & 13 & 15.66 \\
& OP Type II & 21 & 25.30 \\
Ax OP + Perif Op & 3 & 3.61 \\
& Total & 83 & 100.00 \\
\hline
\end{tabular}

The statistical analysis indicated that 37 patients, $44.58 \%$ were diagnosed with $\mathrm{OP}$, in a relatively similar proportion to patients diagnosed with Op- 46 patients, $55.42 \%$ (Table 7).

Table 7. Comparative Diagnosis

\begin{tabular}{|ll|l|l|}
\hline & Frequency & Percent \\
\hline Valid & OP & 37 & 44.58 \\
& Op & 46 & 55.42 \\
& Total & 83 & 100.00 \\
\hline
\end{tabular}

The results obtained after the performed statistical analysis present that a number of 57 patients, $68.67 \%$, followed a treatment with sapropelic mud of Techirghiol inside the sanatorium, while, $31.33 \%$, 26 patients a mud treatment, in contrast therapy regimen in the Cold Baths Department of sanatorium (Table 8).

Table 8 Mud treatment

\begin{tabular}{|ll|l|l|}
\hline & & Frequency & Percent \\
\hline Valid & Inside & 57 & 68.67 \\
& Outside & 26 & 31.33 \\
& Total & 83 & 100.00 \\
\hline
\end{tabular}

81 patients, $97.59 \%$, were identified as having the indication of hydrokinetotherapy in therapeutic pool for the treatment performed. Only 2 patients, $2.41 \%$, did not follow this form of therapy. This result highlights the special therapeuticimportance of hydrokinetotherapy for patients with changes in bone mineral density (34), as is shown in Table 9.

Table 9. Pool treatment

\begin{tabular}{|ll|l|l|}
\hline & Frequency & Percent \\
\hline Valid & Yes & 81 & 97.59 \\
& No & 2 & 2.41 \\
& Total & 83 & 100.00 \\
\hline
\end{tabular}

The statistical analysis indicates that 4 patients, $4.82 \%$, associated the diagnosis of hypertension- high blood preasure (HBP) with decreased bone mineral density. A number of 36 patients, $43.37 \%$, presented the diagnosis of Discopathy (DDD). The association of HBP with Diabetes Mellitus (DM) was registered for a number of 3 patients, 3.61\%, while HBP and DDD were registered for a number of 34 patients, $40.96 \%$. Diabetes was associated with the diagnosis of Discopathy for a single patient, $1.20 \%$. Association of 3 comorbidities, Hypertension, Diabetes mellitus, Discopathy was present in case of 4 patients, $4.82 \%$. A single patient, $1.20 \%$, was analysed as associating other pathologies than those mentioned above with a higher frequency among patients who go to the sanatorium $(35,36)$, according of Table 10.

\begin{tabular}{|c|c|c|c|}
\hline & & Frequency & Percent \\
\hline \multirow[t]{8}{*}{ Valid } & HBP & 4 & 4.82 \\
\hline & DDD & 36 & 43.37 \\
\hline & $\mathrm{HBP}+\mathrm{DM}$ & 3 & 3.61 \\
\hline & HBP+DDD & 34 & 40.96 \\
\hline & DM+DDD & 1 & 1.20 \\
\hline & $\mathrm{HBP}+\mathrm{DM}+\mathrm{DDD}$ & 4 & 4.82 \\
\hline & Other pathologies & 1 & 1.20 \\
\hline & Total & 83 & 100.00 \\
\hline
\end{tabular}

Axial fractures were reported for a number of 2 patients, $2.41 \%$, and a number of 17 patients, $20.48 \%$, recorded peripheral fractures. $2.41 \%$ of patients had both axial and peripheral fractures. 62 patients were identified, $74.70 \%$, as not presenting fractures (Table 11).

Table 11. Presence of Fractures

\begin{tabular}{|c|c|c|c|}
\hline & & Frequency & Percent \\
\hline \multirow[t]{5}{*}{ Valid } & Axial fractures & 2 & 2.41 \\
\hline & $\begin{array}{l}\text { Peripheral } \\
\text { fractures }\end{array}$ & 17 & 20.48 \\
\hline & $\begin{array}{l}\text { Axial and } \\
\text { peripheral } \\
\text { fractures }\end{array}$ & 2 & 2.41 \\
\hline & No fracture & 62 & 74.70 \\
\hline & Total & 83 & 100.00 \\
\hline
\end{tabular}

This point of statistical analysis indicates that only a number of 21 patients, 25.30, presented a fracture, at hospitalisation as a pathological antecedent, while $74.70 \%, 62$ patients did not present this pathology.

A number of 32 patients, $38.6 \%$, did not take any medication to help increase bone mineral density. The administration of bisphosphonates was identified for 9 patients, $10.8 \%$, and of Alpha D3 for 38.6\%, representing 32 out of a total of 83 patients. Mixed administration of two drug classes was reported for a number of 10 patients, $12.0 \%$ (Table 12 ).

Table 12. Medication

\begin{tabular}{|ll|l|l|}
\hline & Frequency & Percent \\
\hline Valid & Bisphosphonates & 9 & 10.8 \\
& Alpha D3 & 32 & 38.6 \\
Mixed medication & 10 & 12.0 \\
No medication & 32 & 38.6 \\
Total & 83 & 100.0 \\
\hline
\end{tabular}


For the distribution by age categories, it is noted that out of 45 hypertensive patients, one person (1.2\%) was in the age range of 50-60 years, the predominant patients were aged between $60-70$ years with a number of 28 people

\begin{tabular}{|l|l|l|l|l|l|}
\hline & & & $\begin{array}{l}\text { Asymptoti } \\
\text { c } \\
\text { Significan } \\
\text { Ve (2- } \\
\text { sided) }\end{array}$ & $\begin{array}{l}\text { Exact Sig. } \\
\text { (2-sided) }\end{array}$ & $\begin{array}{l}\text { Exact Sig. } \\
\text { (1-sided) }\end{array}$ \\
\hline $\begin{array}{l}\text { Pearson Chi- } \\
\text { Square } \\
\begin{array}{l}\text { Fisher's Exact } \\
\text { Test } \\
\text { Pearson Chi- } \\
\text { Square }\end{array}\end{array}$ & 1 & .876 & & \\
\hline $\begin{array}{l}\text { Fisher's Exact } \\
\text { Test }\end{array}$ & 1 & .449 & 1.000 & .696 \\
\hline
\end{tabular}

(33.7.0\%), and there were 16

Between the two variables Diagnosis- Pool There is NO dependency relationship (an association, a connection): $\chi 2$ calc $=0.024, \mathrm{df}=1, \mathrm{p}=0.876>\alpha=0.05$ (37). Also between the two variables Diagnosis- Mud, there is NO dependency relationship_(an association, a connection): $\chi_{\text {calc }}^{2}=0.573, \mathrm{df}=1, \mathrm{p}=0.449>\alpha=0.05$ (Chi-Square Test) (37) (Table 14).

Table 13

\begin{tabular}{|l|l|l|l|}
\hline & & & $\begin{array}{l}\text { Asymptotic } \\
\text { Significance (2- } \\
\text { sided) }\end{array}$ \\
\hline Value & df & .001 \\
\hline Pearson Chi-Square & 20,73 & 2 & .008 \\
\hline
\end{tabular}

Table 15. Box-Plot graphical representation of VAS values at hospital admission /discharge.

\section{Hypothesis Test Summary}

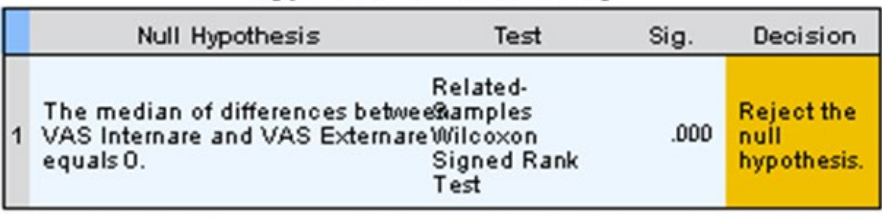

Asymptotic significances are displayed. The signific ance level is 05 .

The values of Visual Analogue Scale (VAS) at hospital admission were between 5 and 10 with a median value of 7 and an IQR between 7 and 8. The VAS values at discharge were between 2 and 7 with a median value of 4 and an IQR between 3 and 5. There are statistically significant differences between the median values of VAS at hospital admission/discharge $(\mathrm{p}<0.001$, Wilcoxon Signed Rank Test) (38). At discharge, the VAS values are lower than at hospital admission (Table 15).

Table 16. Graphical representation (Bar + Error Bars 1SD) of average values of Age for groups in the study.

\begin{tabular}{|c|l|l|l|l|l|}
\hline Diagnosis & $\mathrm{N}$ & $\begin{array}{l}\text { Minimu } \\
\mathrm{m}\end{array}$ & $\begin{array}{l}\text { Maxim } \\
\text { um }\end{array}$ & Mean & $\begin{array}{l}\text { Std. } \\
\text { Deviatio } \\
\mathrm{n}\end{array}$ \\
\hline $\begin{array}{c}\text { OP Age(in } \\
\text { years) }\end{array}$ & 37 & 50.00 & 79.00 & 66.54 & 6.85 \\
\hline $\begin{array}{c}\text { Op Age(in } \\
\text { years) }\end{array}$ & 46 & 51.00 & 79.00 & 63.52 & 6.70 \\
\hline
\end{tabular}

Age values for patients ( Table 16) with OP ranged from 50 to 79 years, with a mean value of 66.54 years and a standard deviation of 6.85 years. Age values for patients with Op ranged from 51 to 79 years, with a mean value of 63.52 years and a standard deviation of 6.70 years. Between the mean age values corresponding to the two groups, it is considered that there are statistically significant differences $(\mathrm{t}=2.020, \mathrm{df}=81, \mathrm{p}=0.047<\alpha$ $=0.05$, Independent Samples t-Test)(39).

Table 17

\begin{tabular}{|l|l|l|l|}
\hline & Value & df & $\begin{array}{l}\text { Asymptotic Significance (2- } \\
\text { sided) }\end{array}$ \\
\hline $\begin{array}{l}\text { Pearson Chi- } \\
\text { Square }\end{array}$ & 8,120 & 3 & .044 \\
\hline
\end{tabular}

Between the two variables Diagnosis at hospital admission-Height, there is a dependency relationship (an association, a connection): $\chi_{\text {calc }}^{2}=8.120, \mathrm{df}=3, \mathrm{p}=0.044$ $<\alpha=0.05$ (Chi-Square Test) (37-39)(Table 17).

Conclusion: Osteoporosis is a pathology that decreases the patient's quality of life (40). There are complementary therapies to pharmacological treatment with immediate and long lasting results. The complex balneo-physical-kinetic treatment is an important link in the treatment of the disabling pathology for the patient, with an important clinical resonance (41-43).

Thereare a number of medical investigations that help determine the risk of fracture, which are not yet widely used: Trabecular Bone Score - involves medical equipment that can determine it and does not exist in all medical centers that provide diagnosis and treatment for osteoporosis, Frax score - even if it does not involve additional determinations compared to osteodensitometry DXA, it is not used by clinicians. As a medical specialty, Recovery, Physical Medicine and Balneology is mainly concerned with the diagnosis of osteoporosis, but also the risk of fracture, this disease is actually involving various functional deficits, which reduces the quality of life of patients with osteoporosis $(44,45)$.

Declaration of conflict of interests. There is no conflict of interest for any of the authors regarding this paper.. 


\section{References}

1. Anonymous Consensus development conference. Diagnosis, prophylaxis and treatment of osteoporosis. Am J Med. 1993; 94:646-50.

2. NIH Consensus Development Panel on Osteoporosis Prevention, Diagnosis and Therapy Osteoporosis prevention, diagnosis and therapy. JAMA. 2001;285(6):785-795.

3. Kanis JA, Melton LJ, 3rd, Christiansen C, Johnston CC, Khaltaev N. The diagnosis of osteoporosis. J Bone Miner Res. 1994;9(8):1137-1141.

4. Marinho BC, Guerra LP, Drummond JB, Silva BC, Soares MM. The burden of osteoporosis in Brazil. Arq Bras Endocrinol Metabol. 2014;58(5):434-443.

5. Pinheiro MM, Reis Neto ET, Machado FS, et al. Risk factors for osteoporotic fractures and low bone density in pre and postmenopausal women. Rev Saude Publica. 2010;44(3):479-485.

6. Baccaro LF, de Souza Santos Machado V, Costa-Paiva L, Sousa MH, Osis MJ, Pinto-Neto AM. Factors associated with osteoporosis in Brazilian women: a population-based household survey. Arch Osteoporos.2013;8(1-2):138.

7. Albrand G, Munoz F, Sornay-Rendu E, Delmas PD. Independent predictors of all osteoporosis-related fractures in healthy postmenopausal women: the OFELY study. Bone. 2003; 32:78-85.

8. Hui SL, Slemenda CW, Johnson CC., Jr Age and bone mass as predictors of fracture in a prospective study. J Clin Invest. 1988;81:1804.

9. Kanis JA, Johansson H, Oden A, Johnell O, De Laet C, Eisman JA, et al. A family history of fracture and fracture risk: a meta-analysis. Bone. 2004; 35:1029-37.

10. Kanis JA, Johnell O, De Laet C, Johansson H, Oden A, Delmas $\mathrm{P}$, et al. A meta-analysis of previous fracture and subsequent fracture risk. Bone. 2004;35:375-382.

11. Kanis JA on behalf of the World Health Organization Scientific Group. Assessment of osteoporosis at the primary health-care level. World Health Organization Collaborating Centre for Metabolic Bone Diseases; University of Sheffield, UK: 2007. Technical Report.

12. Bala Y, Zebaze R, Ghasem-Zadeh A, Atkinson EJ, Iuliano S, Peterson JM, Amin S, et al. Cortical porosity identifies women with osteopenia at increased risk for forearm fractures. J Bone Miner Res. 2014; 29:1356-62.

13. Faulkner KG, Cummings SR, Black D, Palermo L, Gluer CC, Genant HK. Simple measurement of femoral geometry predicts hip fracture: the study of osteoporotic fractures. J Bone Miner Res. 1993; 8:1211-17.

14. Gluer CC. Quantitative Ultrasound--it is time to focus research efforts. Bone. 2007; 40:9-13.

15. Guerri-Fernandez RC, Nogues X, Quesada Gomez JM, Torres Del PE, Puig L, Garcia-Giralt N, et al. Microindentation for in vivo measurement of bone tissue material properties in atypical femoral fracture patients and controls. J Bone Miner Res. 2013; 28:162-8.

16. Keaveny TM, Kopperdahl DL, Melton LJ, III, Hoffmann PF, Amin S, Riggs BL, et al. Age-dependence of femoral strength in white women and men. J Bone Miner Res. 2010; 25:994-1001.]
17. Randall C, Bridges D, Guerri R, Nogues X, Puig L, Torres E, et al. Applications of a New Handheld Reference Point Indentation Instrument Measuring Bone Material Strength. J Med Device. 2013; 7:410051-6.

18. Silva BC, Leslie WD, Resch H, Lamy O, Lesnyak O, Binkley N, et al. Trabecular bone score: a noninvasive analytical method based upon the DXA image. J Bone Miner Res. 2014; 29:518-530.

19. Yang L, Peel N, Clowes JA, McCloskey EV, Eastell R. Use of DXA-based structural engineering models of the proximal femur to discriminate hip fracture. J Bone Miner Res. 2009; 24:33-42.]

20. Cohen A, Dempster DW, Müller R, Guo XE, Nickolas TL, Liu XS, et al. Assessment of trabecular and cortical architecture and mechanical competence of bone by highresolution peripheral computed tomography: comparison with transiliac bone biopsy. Osteoporos Int. 2015; 21:26373.

21. Graeff C, Marin F, Petto H, Kayser O, Reisinger A, Peña J, et al. High resolution quantitative computed tomographybased assessment of trabecular microstructure and strength estimates by finite-element analysis of the spine, but not DXA, reflects vertebral fracture status in men with glucocorticoid-induced osteoporosis. Bone. 2013; 52:56877.

22. Diez-Perez A, Güerri R, Nogues X, Cáceres E, Peña MJ, Mellibovsky L, et al. Microindentation for in vivo measurement of bone tissue mechanical properties in humans. J Bone Miner Res. 2010; 25:1877-85.

23. Wang Y, Sanyal A, Cawthon PM, Palermo L, Jekir M, Christensen $J$, et al. Prediction of new clinical vertebral fractures in elderly men using finite element analysis of CT scans. J Bone Miner Res. 2012; 27:808-16.

24. Kopperdahl D, Aspelund T, Hoffman PF, Sigurdsson S, Siggeirsdottir K, Harris TB, et al. Prediction of new clinical vertebral fractures in elderly men using finite element analysis of CT scans. J Bone Miner Res. 2014; 29:570-80.

25. Silva BC, Leslie WD, Resch H, Lamy O, Lesnyak O, Binkley $\mathrm{N}$, et al. Trabecular bone score: a noninvasive analytical method based upon the DXA image. J Bone Miner Res. 2014; 29:518-30.

26. Hans D, Goertzen AL, Krieg M-A, Leslie WD. Bone Micro-Architecture Assessed by TBS Predicts Osteoporotic Fractures Independent of Bone Density: The Manitoba Study. J Bone Miner Res. 2011;26:2762-9.

27. Winzenrieth R, Michelet F, Hans D. Three-dimensional (3D) microarchitecture correlations with $2 \mathrm{D}$ projection image gray-level variations assessed by trabecular bone score using high-resolution computed tomographic acquisitions: effects of resolution and noise. $\mathrm{J}$ Clin Densitom. 2013;16:287-96.

28. Simonelli C, Leib E, Mossman N, Winzenrieth R, Hans D, McClung M. Creation of an age-adjusted, dual-energy x-ray absorptiometry-derived trabecular bone score curve for the lumbar spine in non-Hispanic US White women. J Clin Densitom. 2014;17:314-9.

29. Ross PD, Davis JW, Epstein RS, Wasnich RD. Pre-existing fractures and bone mass predict vertebral fracture incidence in women. Ann Intern Med. 1991;114(11):919-923. 
30. AssociaçãoMédicaBrasileira e Conselho Federal de Medicina Osteoporose: Diagnóstico. 2011. [Accessed January 20, 2015]. (ProjetoDiretrizes). Available from: http://ww.projetodiretrizes.org.br/diretrizes 10/osteop orose diagnostico.pdf.

31. D. M. Iliescu, P. Bordei, E. V. Ionescu, S. Albina, C. Oprea, B. Obada, A.A. Lupu, T.L. Hangan, M.G. Iliescu. Anatomic-imaging Correlations of Lumbar Disk-vertebral Morphometric Indices. Int J Morphol, 2017; 35 (4), 1553

32. Lupu AA, Ionescu EV, Iliescu MG, Almasan RE, Oprea C, Ion I, Iliescu DM. Effect of Techirghiol specific climate factors on the patients quality of life with degenerative lumbar pain. J Environ ProtEcol. 2018,19 (4), 1857.

33. Iliescu MG, Profir D, Surdu O, Marin V, Demirgean S, Almasan RE, Stanciu LE, Oprea C, Iliescu DM, Ionescu EV. Statistical View Through Balneal Activity In Techirghiol Medical Area. J Environ Prot Ecol. 2018;19(1):382.

34. MG. Iliescu, AA. Lupu, EV. Ionescu, I. Tica, RE Almasan, C. Oprea, DM. Iliescu. Water, nature, techirghiol - long term therapeutic benefits using aquatic exercise for patients with degenerative low back pain. J Environ Prot Ecol. 2019; 20(3):1505-1516

35. Tica I, Lupu A, Botnarciuc M, Petcu L, Oprea C, Badiu RG, Iliescu DM, Ionescu EV, Tica VI; Iliescu MG. Brain Derived Neurotrophic Factor - a Marker for the Balneal Treatment of Chronic Low Back Pain? Rev.Chim.(Bucharest) 2019, 70(9): 3180

36. Almasan RE, Ionescu EV, Iliescu MG, Oprea C, Iliescu DM, Nenciu MI, Golumbeanu M. Techirghiol lake in the context of the integrated development of health tourism. J Environ ProtEcol. 2019;20(1):206-213

37. Petcu, L.C., Analizastatistica cu SPSS-Note de Curs, Ed. Ovidius University Press, Constanţa, 2011, 1-303

38. Petcu, L.C., Petcu, A., Lupu, E.C., Informatica Aplicata si Statistica Experimentala, Ed. Ovidius University Press, Constanţa, 2009, 1-195
39. Lupu, G., Petcu, L.C., Lupu, E.C., Matematiciaplicate şi Biostatistică, Ed. Virom, Constanţa, 2006, 221-293

40. S. Albina, A.-M. Ramazan, E. V. Ionescu, M. G. Iliescu. The role of MRI interpretation in patients with rotator cuff disease. Annals of Rheumatic Diseases (2017),vol.76, issue supl.2. $\quad$ http://dx.doi.org/10.1136/annrheumdis-2017eular.2609

41. C. Oprea, E. V. Ionescu, M. G. Iliescu, R. E. Almasan, A. I. Tucmeanu, D. Oprea, D. M. Iliescu, L. Pazara. Use of balneary cure natural factors from the perspective of practitioners and beneficiaries. Journal of Environmental Protection and Ecology 2020; 21, No 2, 725-731

42. E. V. Ionescu, I. Tica, C. Oprea, DM Iliescu, MG Iliescu. Adiponectin Correlation with Bioclinical Benefits of Using Natural Therapeutic Factors in Knee Osteoarthritis. Acta Endo (Buc) 2017; 13, 308

43. Liliana-Elena Stanciu, Elena-Iuliana Paşcu, ElenaValentina Ionescu, Eduard Circo, Carmen Oprea, Madalina Iliescu. Anti-aging potential of Techirghiol mud therapy through the modulation of pituitary-adrenal axis activity. JEPE Journal of Environmental Protection and Ecology 2017; 18, No 2, 728-736

44. Popa FL, Stanciu M, Bighea A, Berteanu M, Totoianu IG, Rotaru M. Decreased serum levels of sex steroids associated with osteoporosis in a group of Romanian male patients. Rev Romana Med Lab. 2016;24(1):75-82;. ISSN online: 2284-5623; ISSN-L: 1841-6624 www.rrml.ro; DOI:10.1515/rrlm-2016-0014.

45. FL.Popa, M. Stanciu, A. Banciu, M. Berteanu. Association between low bone mineral density, metabolic syndrome and sexsteroids deficiency

in men Acta Endocrinologica (2013/2014 Impact Factor: 0.21) ISSN: $\quad$ 1841-0987, http://www.acta-endo.ro/, 2016 12(4):418-422, DOI:10.4183/aeb.2016.418 